\title{
Why have global shark and ray landings declined: improved management or overfishing?
}

\author{
Lindsay N K Davidson ${ }^{1}$, Meg A Krawchuk ${ }^{2}$ \& Nicholas K Dulvy ${ }^{1}$ \\ ${ }^{1}$ Earth to Ocean Research Group, Biological Sciences, Simon Fraser University, 8888 University Drive, Burnaby, BC, \\ Canada, V5A 1S6; ${ }^{2}$ Landscape and Conservation Science Research Group, Department of Geography, Simon Fraser \\ University, 8888 University Drive, Burnaby, BC, Canada, V5A 1S6
}

\begin{abstract}
Global chondrichthyan (shark, ray, skate and chimaera) landings, reported to the United Nations Food and Agriculture Organization (FAO), peaked in 2003 and in the decade since have declined by almost 20\%. In the FAO's 2012 'State of the World's Fisheries and Aquaculture' report, the authors 'hoped' the reductions in landings were partially due to management implementation rather than population decline. Here, we tested their hypothesis. Post-peak chondrichthyan landings trajectories from 126 countries were modelled against seven indirect and direct fishing pressure measures and eleven measures of fisheries management performance, while accounting for ecosystem attributes. We found the recent improvement in international or national fisheries management was not yet strong enough to account for the recent decline in chondrichthyan landings. Instead, the landings declines were more closely related to fishing pressure and ecosystem attribute measures. Countries with the greatest declines had high human coastal population sizes or high shark and ray meat exports such as Pakistan, Sri Lanka and Thailand. While important progress had been made, country-level fisheries management measures did not yet have the strength or coverage to halt overfishing and avert population declines of chondrichthyans. Increased implementation of legally binding operational fisheries management and species-specific reporting is urgently required to avoid declines and ensure fisheries sustainability and food security.
\end{abstract}

Keywords Conservation, Convention on International Trade in Endangered Species, elasmobranch, fin trade, fishing mortality, National Plans of Action
Correspondence: Lindsay N K Davidson, Earth to Ocean Research Group, Biological Sciences,

Simon Fraser University, 8888 University Drive, Burnaby, BC, Canada, V5A 1 S6 Tel.: +778-782-3989 E-mail: ldavidso@sfu. ca

Received 21 Jul 2014 Accepted 19 Mar 2015

$\begin{array}{lr}\text { Introduction } & \mathbf{2} \\ \text { Methods } & 3 \\ \text { Analytical approach } & 3 \\ \text { Selection, filtering and quality control of FAO landings data } & 4 \\ \text { Response variable - country-by-country chondrichthyan landings trajectories } & 4 \\ \text { Measures of fishing pressure } & 4 \\ \text { Indirect fishing pressure } & 4 \\ \text { Direct fishing pressure } & 5 \\ \text { Measures of fisheries management performance } & 5 \\ \text { Indirect measures of fisheries management performance } & 5\end{array}$ 
Direct measures of fisheries management performance

Sensitivity and resilience of the species and surrounding ecosystem

Ecosystem and species attributes

Statistical analysis

Results

What percentage of global reported landings were reported from countries with management measures?

Was the global trend sensitive to influential countries or reporting categories? 12

What measures were most important in describing landings trajectories? 13

Discussion

Is there additional evidence for shark and ray population declines?

Did aggregate reporting influence our interpretation?

What are the global priorities to promote shark and ray fisheries sustainability?

8

8

8

9

\section{Introduction}

Sharks, rays, skates and chimaeras (chondrichthyans, hereafter 'sharks and rays') are one of the most evolutionary distinct fish lineages and play important functional roles in marine environments (Stevens et al. 2000). They are commercially valuable for their fins, meat, liver oil, gill rakers, leather, and are an important source of food security. Shark and rays were once considered the less valued by-catch of more profitable fisheries stocks, such as tuna (Scombridae) and cod (Gadidae) (Stevens et al. 2005). The rising demand for products, coupled with the decline of valuable fisheries, however, resulted in rising catch and retention of shark and rays (Clarke et al. 2006b; Lack and Sant 2011). Until recently, directed and by-catch shark and ray fisheries were subjected to little management and were of low management priority (United Nations General Assembly 2007; Fischer et al. 2012).

Concerns for the sustainability of shark and ray fisheries prompted advances in shark and ray fisheries management tools over the past 20 years. For example, in 1999, the United Nations Food and Agriculture Organization (UN FAO) recommended the development and implementation of National Plans of Action for sharks (NPOA shark hereafter referred to as Shark-Plans) by signatory nations to, preferably, be completed before 2001 (UN FAO 2013). These non-binding Shark-Plans had ten aims encompassing sustainability, threatened species, stakeholder consultation, waste minimization, ecosystem considerations, and improved monitoring and reporting of catch, landings and trade. Aside from Shark-plans, other global initiatives in chondrichthyan conservation and management over the past 20 years include, but are not limited to (i) the introduction of bans on fin removal and carcass disposal at sea (Clarke et al. 2006b, 2013; Fowler and Séret 2010; Biery and Pauly 2012); (ii) the application of trade regulations of marine fishes through the Convention on International Trade in Endangered Species (CITES) (Vincent et al. 2013); (iii) international agreements to prevent Illegal, Unregulated and Unreported (IUU) fishing (Field et al. 2009; Witbooi 2014); and (iv) management and conservation of migratory sharks and rays through the Convention of Migratory Species Memorandum of Understanding for Sharks (CMS MoU sharks) (Fowler 2012).

Despite the advances in shark and ray fisheries management, there were concerns that chondrichthyan fisheries were following the predictable pattern shown by unregulated, open-access fisheries: declining catch per unit effort, collapse and serial depletion (Pitcher and Hart 1982; Lam and Sadovy de Mitcheson 2011). Indeed, shark and 
ray landings increased $227 \%$ from 1950 (the first year of data collection) to the peak year in 2003 and subsequently declined $15 \%$ by 2011 (FAO $2013 \mathrm{~b})$. The authors of the 2010 State of the World's Fisheries and Aquaculture (SOFIA) expressed that they 'hoped' this reduction in shark and ray landings was due to a rise in sustainable fisheries and hence reduced catch, rather than population declines (FAO 2010). There was little comment on shark and ray landings declines in the 2012 SOFIA report; however, the most recent SOFIA concluded, 'a simple explanation for the recent [landings] trends is not possible' (FAO 2014).

Here, we tested FAO's hypothesis and assessed whether country-by-country variation in shark and ray landings from 2003 to 2011 was best explained by indicators of overfishing or fisheries management performance. We also accounted for ecosystem attributes as they have been shown to constrain fisheries catch (Chassot et al. 2010). If the hope expressed in the SOFIA 2012 report was correct, we expected landings reductions to be in response to management implementation. Conversely, if the interpretation was not correct, we expected landings reductions to be unrelated to management performance indicators and more closely related to indirect and direct measures of fishing pressure.

\section{Methods}

\section{Analytical approach}

The magnitude and trajectory of fisheries landings can be characterized as a function of exposure to fishing pressure which can be modified by fisheries management performance and by the intrinsic sensitivity and resilience of the ecosystem (Fig. 1). A series of metrics can be used as indirect drivers of fishing pressure such as human coastal population size and density (Newton et al. 2007) and reliance on fish for income and dietary protein (Allison et al. 2009; Smith et al. 2010). The degree to which these indirect drivers translate into fishing pressure and mortality is modified by the form and strength of fisheries management control that can be characterized with metrics such as scientific capacity, Gross Domestic Product (GDP) and Human Development Index (HDI) (Allison et al. 2009; Mora et al. 2009; Pitcher et al. 2009). International and national protections, or more

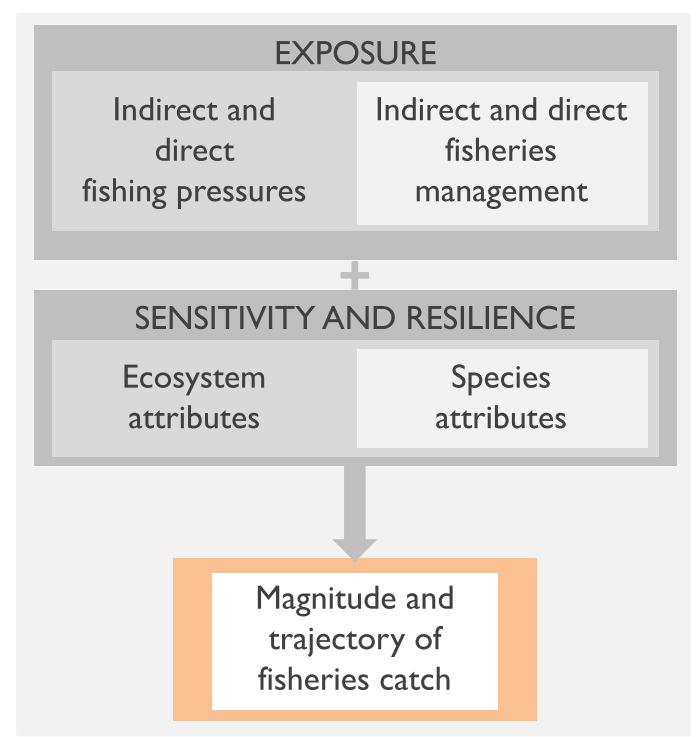

Figure 1 The magnitude and trajectory of fisheries landings are a function of exposure to fishing, which is ameliorated by the form and strength of fisheries management and the sensitivity and resilience of the ecosystem and species.

diffuse measures that are precursors to a good management regimes, may promote reduced catch (Clarke et al. 2006b). Metrics that quantify intrinsic sensitivity at the ecosystem level include the size of ecosystem and primary productivity (Myers et al. 2001; Chassot et al. 2010; Watson et al. 2013) and at the species level include species richness, or measures of population growth rate (García et al. 2008; Dulvy et al. 2014b).

First, we describe the collection of the response variable - the trajectory of the landed catch of chondrichthyans followed by the plausible explanatory variables broadly classed as exposure to (i) drivers of fishing pressure, (ii) fisheries management performance, and (iii) sensitivity and resilience of the surrounding ecosystem and species (see Table S1 for a summary of measures used in this analysis).

\section{Selection, filtering and quality control of FAO landings data}

We extracted all shark, ray, skate and chimaera landings by country from the earliest year of reporting (1950) to, at the time of this analysis, the most recent (2011) from the FAO FishSTAT database (FAO 2013b). Chimaeras are included in this analysis; however, they are a small percentage 
of global landings. We used the 'Sharks, rays, chimaeras' category of the 'species by ISSCAAP' (International Standard Statistical Classification of Aquatic Animals and Plants) group. Within this broad group were 135 species and 30 aggregate non-species-specific 'nei' - not elsewhere indicated - reporting categories, which, summed to 217416 tonnes and $548687 \mathrm{t}$ in 2011, respectively, for a total of $766103 \mathrm{t}$. Examples of nei categories include 'sharks, rays, skates, etc, nei' and 'threshers, nei'. The peak of the aggregate global shark and ray landings was 2003 at 895743 t. In total, 155 countries and overseas territories reported to the FAO, however, countries with no values, or with landings that remained unchanged, as well as overseas territories, and the 'other nei' categories were removed for the Random Forest analysis.

\section{Response variable - country-by-country chondrichthyan landings trajectories}

Landings across reporting categories were summed for each country by year. We calculated both the average and the change in reported landings. Average landings between 2003 and 2011 were calculated to account for the size of the shark and ray fishery (Fig. 2a). Change in reported landings was calculated as the absolute difference between averages of 2001-2003 and 2009-2011 (Fig. 2b).

\section{Measures of fishing pressure}

\section{Indirect fishing pressure}

Three indirect measures of fishing pressure were included in the analysis: coastal human population size, marine protein available for consumption and percent of threatened species within national waters (Table S1). Human coastal population size and the available marine protein for consumption are related to reduced biomass and unsustainable fishing on coral reefs at island and country scales (Dulvy et al. 2004; Newton et al. 2007; Cinner et al. 2009). Human coastal population size was captured through nominal coastal settlement data and defined as the number of persons living in rural and urban areas within $100 \mathrm{~km}$ of the coun-

(a) Percent of global landings

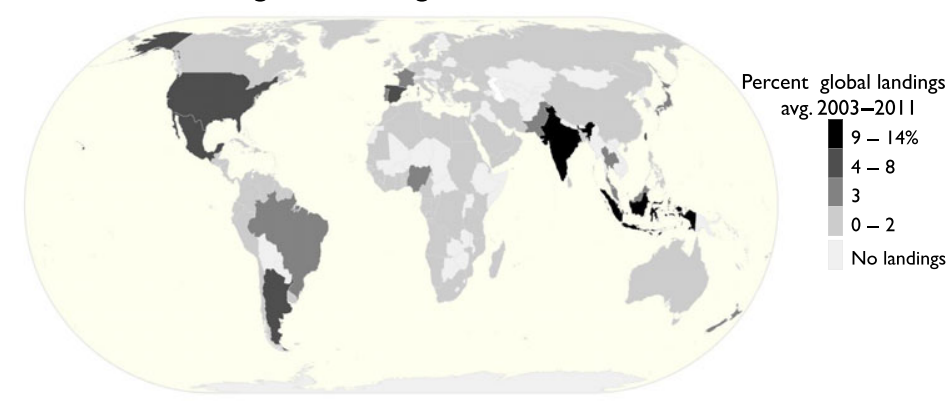

(b) Change in reported shark and ray landings

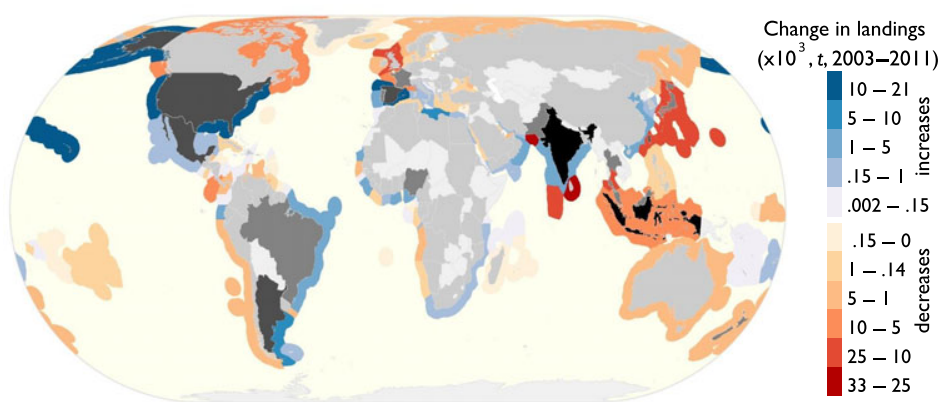

Figure 2 Global distribution of (a) country-specific shark and ray landings averaged between 2003 and 2011 and mapped as a percent of the total. Landings include overseas fishing and all reporting categories ('nei' or species-specific), (b) the difference between the averages of landings reported in 2001-2003 and 2009-2011. Mapped to the national waters that extend $200 \mathrm{~nm}$ from the coast for visual purposes. 
try's coast as of 2011 (NASA Earth Data 2014). National marine protein supply was defined as grams per capita per day of marine fish protein available for consumption and represented reliance on marine resources (Allison et al. 2009; FAO 2013b). The dates of the marine protein supply estimates for each country ranged from 1969 to 2009; however, only 22 countries had entries earlier than 2009. The state of a country's shark and ray populations was likely to be captured by the percent of threatened species within national waters. We therefore calculated the percent of shark and ray species classified by the International Union for the Conservation of Nature (IUCN) to have an elevated risk of extinction those species categorized according to IUCN Red List criteria as (Vulnerable, Endangered or Critically Endangered) within each country's national waters (EEZ - Exclusive Economic Zone that extends 200 nautical miles from the coast) (Dulvy et al. 2014a).

\section{Direct fishing pressure}

Ideally, we would have included direct measures of fishing pressure such as fishing intensity, fishing effort and fishing mortality estimates. The coverage of fisheries by stock assessments and other data intensive measures, however, is limited and only represents $16 \%$ of reported teleost fisheries (Ricard et al. 2012). We included and described four measures of exploitation pressure: overseas landings, the volume of shark and ray meat exports, the volume of fins exported to Hong Kong and estimated Illegal Unreported Unregulated (IUU) fishing within national waters (Table S1).

Overseas shark and ray landings were defined as those taken from beyond each country's EEZ from 2003 to 2011. Our definition, however, only includes landings from outside the FAO major fishing areas as spatial mismatch between a country's EEZ and a FAO major fishing area exists with the boundaries of the latter extending farther beyond any EEZ. Therefore, our definition of overseas landings is a combination of international and national waters and only removes unambiguous overseas fishing (such as Belize landings from Indian Ocean) and hence will be an underestimate. China, Hong Kong, Norway and Zanzibar only reported landings from overseas waters.

The volume of shark and ray meat exports was included as a measure of fishing pressure as shark and ray meat is a globally traded commodity. We included the amount of shark and ray meat exports reported to the FAO under 13 commodity codes (FAO 2013b) between 2003 and 2009 which included fins and liver oil, of mainly sharks, but also to a lesser extent rays, skates and chimaeras. Spain, Taiwan, Canada, Japan, United Kingdom and Indonesia reported the largest meat exports at $11608 \mathrm{t}, 4684 \mathrm{t}, 3813 \mathrm{t}, 3748 \mathrm{t}$, $3534 \mathrm{t}$ and $3497 \mathrm{t}$, respectively. Meat exports between 2003 and 2009, on average, increased $277 \mathrm{t}$ (Table S2) with Uruguay and Taiwan reporting the largest increases (16 283 t and 15 493, respectively). We used the volume of fins countries exported to Hong Kong based on census trade statistics for 2011 (The Government of the Hong Kong Special Administrative Region of the People's Republic of China 2012). Note, this metric represented $50 \%$ of the global trade, included fins from high seas catches and non-adjacent EEZs and ignored import-reexport of fins, particularly from European Union (EU) countries and from those that are large trade entrépots such as UAE and Singapore (Clarke 2004a,b; Hareide et al. 2007). IUU fishing estimates were calculated at the FAO major fishing region scale (MRAG and Fisheries Ecosystems Restoration Research 2008). Each country's value was derived by summing the lower IUU estimates for each FAO major fishing area that corresponded with a country's EEZ.

\section{Measures of fisheries management performance}

Indirect measures of fisheries management performance Ideally, measures of fisheries management would have been country-by-country lists of the shark and ray fisheries management instruments implemented that ensured sustainable fishing. These instruments would have included science-based precautionary catch limits, prohibitions on catch (particularly of threatened species), reduction of by-catch, and habitat and spatial protections in place (Barker and Schluessel 2005). Such data are not readily or consistently available at the global scale for a comparative national analysis. The paucity of data could be due to poorly documented fisheries management but more likely reflects the lack of systematically applied shark and ray fisheries regulations (Fischer et al. 2012; Dulvy et al. 2014a). We therefore developed a series of indirect management performance measures by country that described enabling conditions that promoted good management. 
Fisheries management implementation and effectiveness are influenced by the economic and development status of a country. We therefore included GDP, HDI and percent of Data Deficient (DD) species in this analysis. Countries with high income, or high development status, have significantly better fisheries management than lowincome countries (Mora et al. 2009; Pitcher et al. 2009; Gutiérrez et al. 2011). GDP is the sum gross, nominal value of a country's economy and is positively correlated with overall management effectiveness (Mora et al. 2009). Countries with high HDI scores, a composite of health, education and living standards metrics, are more successful at achieving sustainable fisheries (Gutiérrez et al. 2011; United Nations Development Programme 2011). Shark and ray species categorized by the IUCN as DD, are those that lack sufficient information to be assigned to a Red List category. Therefore, we included the percent of DD species found within a country's EEZ as a measure of scientific capacity.

Direct measures of fisheries management performance We collated data for nine measures of direct fisheries management that were finalized up to 2012 (Table S1). We feel that the measures we collated were salient because they were global, comparable, and supported by the international community. We categorized the uptake and implementation of international policies including the Port State Measures Agreement (PSMA), which is not specific to sharks and rays, and the Convention of Migratory Species Memorandum of Understanding for sharks (CMS MoU sharks). Three plus the 22 EU maritime countries had ratified, approved or accessioned the PSMA (Fig. 3a). Implementation of the PSMA results in ports with stricter regulations to prevent illegally caught fish from being unloaded. For sharks and rays, this means enforcement on fishing that contravened regulations, such as finning or fishing illegally in another country's EEZ. By 2011, 20 countries were signatory to the PSMA, but had not yet ratified the agreement (FAO 2013a). Twenty-three countries, plus the $22 \mathrm{EU}$ maritime countries, were signatories to the CMS MoU sharks agreement, which had listed seven migratory shark species under Appendix 1; White (Carcharodon carcharias), Basking (Cetorhinus maximus), Whale (Rhincodon typus), Shortfin Mako (Isurus oxyrinchus), Longfin Mako (Isurus paucus), Spiny Dogfish (Northern
Hemisphere) (Squalus acanthias) and Porbeagle (Lamna nasus). Species listed on Appendix 1 are to be the focus of a global or national conservation plan that 'promotes the conservation of migratory sharks' (CMS 2013). The objectives of the conservation plan include (1) research and monitoring of populations, (2) ensuring directed and non-directed fisheries are sustainable, (3) promoting protection of critical habitat, (4) increasing public awareness and (5) enhancing government cooperation (CMS 2013) (Fig. 3b). Support for CITES listings was not included in this analysis as membership to CITES was not specific to sharks and rays, and voting direction of countries for listing species onto appendices was mostly not recorded (a motion generally passed beforehand to ensure voting anonymity).

Twenty-two finalized Shark-Plans were scored on a categorical three-point scale according to how comprehensively the ten objectives of sustainable shark fisheries and conservation were addressed (UN FAO 2013). For each country with a SharkPlan, objectives were scored as to whether it was: met comprehensively $(=2)$; mentioned, but not comprehensively addressed $(=1)$; or not addressed $(=0)$. The scores had a maximum score of 20 if all 10 objectives were comprehensively addressed. The Shark-Plans performance scores ranged from five (Japan) to the highest 17 (Australia), or 25$85 \%$ of the objectives met (Fig. 3c). We also counted the number of years since Shark-Plan completion up to the year of most recent FAO landings data (2011), with values ranging from 1 to 10 years. There was a high positive correlation between completion year and the strength of Shark-Plans (Pearson's, $r=0.67$ ) (Fig. S1).

Finning is the act of cutting off a shark or rays fins and dumping the carcass overboard (Clarke et al. 2006a,b; Camhi et al. 2008; Biery and Pauly 2012). Finning mostly refers to sharks, but rays have some of the most valuable fins (Dulvy et al. 2014a). Finning bans were scored on an ordinal scale such that (up to 2012) (i) fins-attached, shark and ray fins not removed $(n=16$ countries plus 18 EU maritime countries) was a preferable management measure to (ii) fin-to-carcass ratio, fins separated from bodies but weight of fins must be a specific ratio of the bodies $(n=4$ plus 2 EU [Spain and Portugal]), which in turn was better than, (iii) no finning ban $(n=86$; Fig. $3 d)$. Countries with finalized finning ban strategies were expected to initially report increased landings as 
(a) Port State Measures Agreement (PSMA)

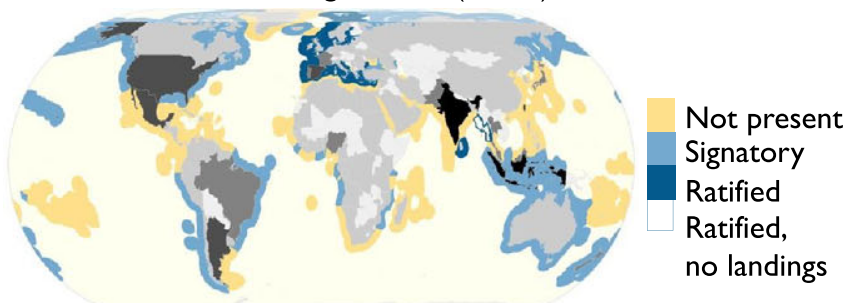

(b) CMS MoU sharks agreement

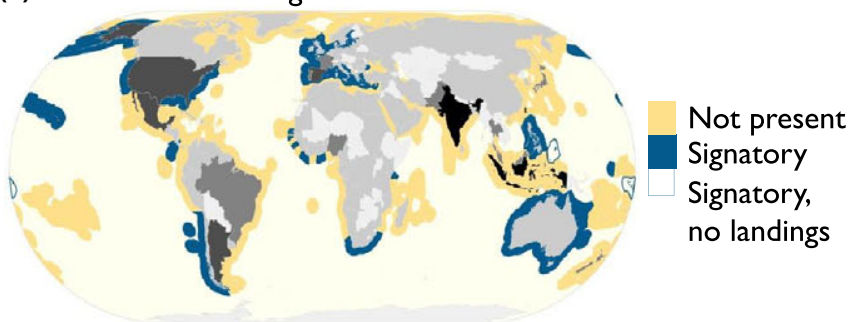

(c) Shark-plan strength, percentage objectives met

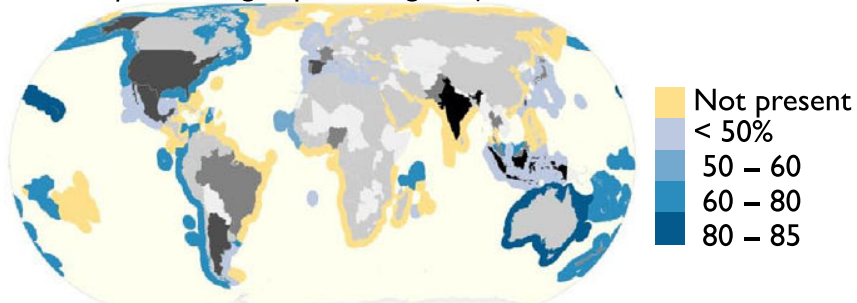

(d) Finning management strength

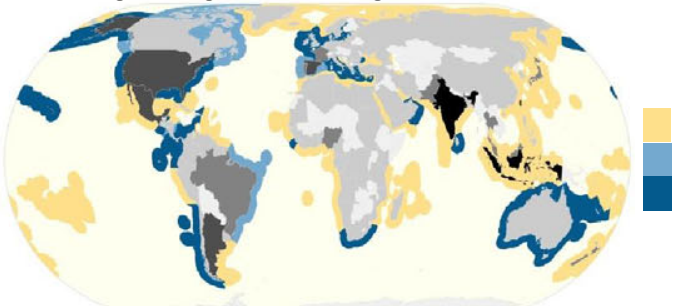

Not present

Fin-to-carcass ratio

Fins attached

(e) Commercial fishing bans (CFB)

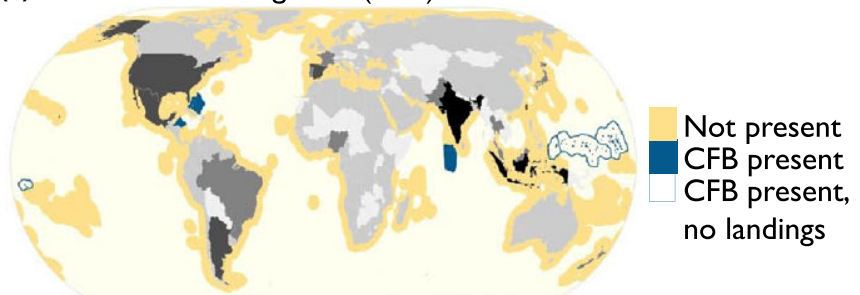

Figure 3 Spatial distribution of the direct management measures we considered finalized up to the year 2012 to correspond with the FAO landings data. (a) Countries that are signatory to, or have ratified the PSMA. EU, Sri Lanka and Myanmar (which did not report shark and ray landings) ratified the agreement. (b) Countries that were signatory to the CMS MoU sharks. Tuvalu and Palau signed the agreement and had not reported shark or ray landings. (c) The percentage of the ten objectives of sustainable fishing that were met. (d) The presence and strength of finning regulations; finsattached $>$ fin-to-carcass ratio $>$ none. The variability of finning bans are not captured here (such as South Africa's $8 \%$ fin-to-carcass (dressed weight) ratio for domestic vessels but 14\% ratio for foreign vessels; or the variation in Australia's finning regulations in territorial waters). (e) The location of commercial fishing bans (CFB) for sharks. 
carcasses, and not just fins, would be brought back to port.

Shark 'sanctuaries' (hereafter 'commercial fishing bans') are a form spatial protection as branded by environmental non-governmental organization the Pew Charitable Trust. Up to 2012, the following countries had declared commercial fishing bans: Palau, Maldives, Tokelau, Micronesia, Marshall Islands, Honduras and Bahamas. Commercial fishing bans extend to a country's EEZ waters and ban commercial fishing for sharks, but not rays (Davidson 2012; PEW charitable trusts 2013) (Fig. 3e). They are neither no-take, nor no-entry, and artisanal fishing or landed by-catch is permitted. Commercial fishing bans were included in this analysis, as opposed to all MPAs, to evaluate their stated goal of shark conservation.

Data collection and availability is an essential precursor to fisheries management. Therefore, we calculated the percentage of a country's landings reported to the species level, relative to the total (Table S1; Fig. S2). Finally, we included a score that evaluated compliance to UN Code of Conduct for responsible fisheries and was assigned to the 53 countries that reported more $(96 \%)$ of the global marine catch (in 1999) (Pitcher et al. 2009). The ranking, however, was not included in the final analysis as the majority of countries we analysed did not have a score.

\section{Sensitivity and resilience of the species and surrounding ecosystem}

\section{Ecosystem and species attributes}

We used ecosystem area, species richness and the number of endemic species, as an index of sensitivity and resilience (Table S1). We used EEZ area as a measure of ecosystem size (Chassot et al. 2010; VLIZ 2012). There is a wide range of theoretical and empirical work that relates species richness and diversity to population stability (Loreau et al. 2001; Anderson et al. 2013; Mellin et al. 2014). The species richness of each nation's EEZ was calculated using the IUCN SSG (Shark Specialist Group 2013) Extant of Occurrence (EOO) distribution maps for 1041 sharks and rays, however, exclusively freshwater species were not included. Endemicity was defined as species with range sizes within the lower quartile of total shark and ray range size $\left(<121509 \mathrm{~km}^{2}\right)$ (Pompa et al. 2011).

\section{Statistical analysis}

To measure the share of global shark and ray landings reported from countries with potentially sustainable fisheries, we calculated average reported landings from countries with direct management measures finalized: signatory to PSMA or CMS MoU sharks, have finalized a Shark-Plan, finning ban or a commercial fishing ban. We also considered combinations of the presence of management measures. A country was assigned a value ranging between no management measures present $(=0)$ or all management measures present $(=5)$. All reported landings were included regardless of location or reporting category. Finally, excluding countries that reported an increase in landings, we determined the percentage of the decline reported from countries with any combinations of these management measures.

As a second step in the data analysis, we determined whether particular countries or reporting categories were influential on the global trend in landings from 2003 to 2011 using a Jackknife analysis (Juan-Jordá et al. 2011). Countries that reported large increases in landings may mask a steeper global decline, while countries with large declines may drive the global trend. To determine influence, we examined how the global trajectory from 2003 to 2011 changed in absence of the reported landings from each of the ten countries that reported the greatest landings (2003-2011). We repeated this analysis for the ten reporting landings categories with the greatest share of the global landings which included a combination of species and aggregate taxonomic categories.

To tackle the overall question of whether management or fishing pressure measures were associated with declining trajectories, we used Random Forest regression. Random Forest is a powerful approach for assessing which explanatory variables account for the most variance in a response, without requiring restrictive assumptions about the nature of relationship between the two (Liaw and Wiener 2002). Each Random Forest model had 100001 iterations, with the default value of the number of variables randomly sampled for each decision tree split, and data subsetted more than once (with replacement). Analysis was completed using the randomForest package (Liaw and Wiener 2002) for the statistical software R (R core team, 2014). 
To compare and test the sensitivity of the results, we ran Random Forest models on four subsets of the data. First, a model with explanatory variables that included only those countries reporting a decline in catch. Second, the global catch trend is driven mostly by a large aggregate of 'sharks, rays, skates, etc, nei', so we examined drivers of only this subset of the catch. Third, the EU countries have a largely coherent governance framework and we tested whether the global pattern was sensitive to the exclusion of these countries. Fourth, increased landings might arise from better reporting and management, so we considered only those countries reporting an increase in landings separately from those showing declines.

Here, we are interested only in the interpretation of important variables. Therefore, we ranked explanatory variables according to variable importance measured by the mean standard error (MSE) in descending order. MSE indicates the difference between model performances with actual data compared to a model with the randomly generated variable. High MSE values denote the most important variables and indicate better model performance with actual values. Negative MSE values caution that randomly generated explanatory variables are performing better than our hypothesized predictors (Strobl et al. 2008). Partial dependence plots, the visual tool associated with Random Forest, show marginal effects of predictor variables on the response. The $y$-axis is the average predicted response across trees at the value of $x$.

\section{Results}

More than half (86) of the 147 countries and overseas territories reported reductions in shark and ray landings. The change in landings ranged between a $32281 \mathrm{t}$ decline (Pakistan) and an increase of $20065 \mathrm{t}$ (Spain). The average change in landings, across all reporting countries, was an $837 \mathrm{t}$ decline, with a median of a $3 \mathrm{t}$ decline. In total, across all reporting countries, the global landings declined by $129642 \mathrm{t}$ (15\%), with a $244530 \mathrm{t}$ change for countries reporting declines, and $114888 \mathrm{t}$ change for those countries reporting increases. Half of the decline in landings, regardless of reporting category or fishing location, occurred in just five countries: Pakistan (32 $281 \mathrm{t})$, Sri Lanka (25 $176 \mathrm{t})$, Thailand (21 051 t), Taiwan Province of China (18 $919 \mathrm{t}$ ) and Japan (15 471 t; Table 1a). Correspondingly, the broad FAO fishing areas with the greatest decline in landings occurred in the western Central Pacific (49 $920 \mathrm{t}$ ) and the Western Indian Ocean (45 $928 \mathrm{t}$ ).

The greatest declines, over the same time period, in species-specific categories, were Spiny Dogfish (S. acanthias, Squalidae), 12170 t; Whip Stingray (Dasyatis akajei, Dasyatidae), 4557 t; Portuguese Dogfish (Centroscymnus coelolepis, Somniosidae), 3510 t; Leafscale Gulper Shark (Centrophorus squamosus, Centrophoridae), 2351 t; and Narrownose Smooth-hound (Mustelus schmitti, Triakidae) $1070 \mathrm{t}$. Three of these species are categorized, globally, as threatened: Vulnerable (Spiny Dogfish, Leafscale Gulper Shark) and Endangered (Narrownose Smooth-hound). The majority of these populations declined due to intensive fishing pressure. Consequently, Spiny and Portuguese dogfish, and Leafscale Gulper Shark are currently managed with a zero total allowable catch (TAC) in EU waters. In the United States, the Spiny Dogfish fishery re-opened in 2011 under quotas (Table 1b).

Countries with the greatest increases in landings over the same time period were Spain (20 065 t) then the United States (10 698 t), followed by Argentina (8748 t), Libya (7574 t), India (4998 t) and Nigeria (4944 t) (Table S3). United States had the greatest increase when excluding our previously defined overseas landings. Spain reported the greatest landings increases mainly comprised of Blue Shark and to a lesser extent the Cuckoo Ray (Leucoraja naevus, Rajidae) and Shortfin Mako, (I. oxyrinchus, Lamnidae). In terms of management, the Blue Shark and the Shortfin Mako fisheries currently have no catch limits in the EU; the Cuckoo Ray is subject to a combined total allowable catch (TAC) for all species of skate and ray in EU waters. The greatest landings increase by FAO fishing area was recorded in the eastern central Atlantic (26 $674 \mathrm{t}$ ) and south-west Atlantic (20 $083 \mathrm{t})$.

From a global perspective, the largest increase in categories was Blue Shark (62 907 t), 'Stingrays, butterfly rays nei' (40 $444 \mathrm{t}$ ), and to a lesser extent 'Thresher sharks nei' (15 880 t), 'Smoothhounds nei' (6113 t), 'Dogfish sharks nei' (4705 t) and Little Skate (Leucoraja erinacea, Rajidae; 4520 t). Indonesia switched reporting, however, in 2005 from 'sharks, ray, skates, etc, nei' and 'rays, stingrays, mantas, nei' into 11 finer resolution reporting categories. Consequently, an increase in a reporting category may be a result of 
Sharks and rays - overfished and unmanaged L K Davidson et al.

Table 1 Countries and species reporting categories with the greatest changes between 2003 and 2011 in descending order. (a) The five countries that reported the greatest declines in landings, the reporting categories for each country and associated management measures within that country. (b) Species-specific reporting categories with the greatest landings reductions, the countries that reported changes in those categories and the associated management measures for that fishery. Only changes greater than a decline of 500 tonnes or greater than an increase of $500 \mathrm{t}$ were included in the table for brevity.

\begin{tabular}{|c|c|c|c|}
\hline $\begin{array}{l}\text { (a) } \\
\text { Country }\end{array}$ & Reporting category & $\begin{array}{l}\text { Diff. in landings } \\
(2003-2011, t)\end{array}$ & Management \\
\hline Pakistan & $\begin{array}{l}\text { Requiem sharks nei } \\
\text { Rays, stingrays, mantas nei } \\
\text { Guitarfishes, etc, nei }\end{array}$ & $\begin{array}{l}-19161 \\
-11970 \\
-1150\end{array}$ & $\begin{array}{l}\text { 'accessible fishery legislation of Pakistan did not contain } \\
\text { any references to sharks' (Fischer et al. 2012) }\end{array}$ \\
\hline Sri Lanka & $\begin{array}{l}\text { Sharks, rays, skates, etc, nei } \\
\text { Silky Shark } \\
\text { Blue Shark } \\
\text { Oceanic Whitetip Shark } \\
\text { Thresher sharks nei }\end{array}$ & $\begin{array}{l}-19019 \\
-2798 \\
-1366 \\
-889 \\
-698\end{array}$ & $\begin{array}{l}\text { 'a shark finning ban is the only fisheries management } \\
\text { measure explicitly directed at sharks' (Fischer et al. 2012). } \\
\text { Sri Lanka prohibited the catch, retention, trans-shipment, } \\
\text { landing, storage and/or sale of whole bodies or parts of } \\
\text { common, bigeye or pelagic thresher sharks } \\
\text { (took effect in 2012) (Shark Advocates International 2012) }\end{array}$ \\
\hline Thailand & $\begin{array}{l}\text { Sharks, rays, skates, etc, nei } \\
\text { Rays, stingrays, mantas nei }\end{array}$ & $\begin{array}{l}-10665 \\
-10387\end{array}$ & $\begin{array}{l}\text { 'lack of data and trained staff, the absence of systematic } \\
\text { monitoring and control of shark resources... and the } \\
\text { absence of a baseline assessment on the status of shark } \\
\text { populations' (Fischer et al. 2012) }\end{array}$ \\
\hline $\begin{array}{l}\text { Taiwan, Province } \\
\text { of China }\end{array}$ & $\begin{array}{l}\text { Sharks, rays, skates, etc, nei } \\
\text { Rays, stingrays, mantas nei } \\
\text { Silky Shark } \\
\text { Shortfin Mako } \\
\text { Blue Shark }\end{array}$ & $\begin{array}{c}-24536 \\
-1319 \\
1058 \\
1855 \\
3562\end{array}$ & $\begin{array}{l}\text { NPOA - two stock assessments to be completed and a } \\
\text { TAC (total allowable catch) management scheme will be } \\
\text { implemented if the shark resources declined significantly; } \\
\text { finning management was introduced (2012) (Fishery } \\
\text { Agency 2004). Since 2003, commercial fishing vessels } \\
\text { were required to report Blue, Mako and Silky Shark catches } \\
\text { separately (Fischer et al. 2012) }\end{array}$ \\
\hline Japan & $\begin{array}{l}\text { Sharks, rays, skates, etc, nei } \\
\text { Whip Stingray }\end{array}$ & $\begin{array}{l}-10915 \\
-4557\end{array}$ & $\begin{array}{l}\text { NPOA does not have specific measures for reduction of } \\
\text { shark catches (Fisheries Agency 2009) }\end{array}$ \\
\hline $\begin{array}{l}\text { (b) } \\
\text { Reporting category }\end{array}$ & Country & $\begin{array}{l}\text { Diff. in landings } \\
(2003-2011, t)\end{array}$ & Management \\
\hline Spiny Dogfish & $\begin{array}{l}\text { United Kingdom } \\
\text { Canada } \\
\text { New Zealand } \\
\text { France } \\
\text { Ireland } \\
\text { Norway } \\
\text { United States of America }\end{array}$ & $\begin{array}{l}-6227 \\
-5382 \\
-974 \\
-881 \\
-865 \\
-781 \\
3907\end{array}$ & $\begin{array}{l}\text { Spiny Dogfish were classified as Critically Endangered in the } \\
\text { northeast Atlantic. Their population was estimated to have } \\
\text { fallen by } 95 \% \text { over } 100 \text { years. In the EU, in 2011, the TAC } \\
\text { was set to zero to allow the population to recover } \\
\text { (Fordham 2004). Canada has a quota on the Pacific and } \\
\text { Atlantic coasts; however, the Atlantic quota was not based } \\
\text { on scientific advice, and there were no restrictions on } \\
\text { by-catch or discards (DFO 2007). In the United States, the } \\
\text { Spiny Dogfish fishery re-opened on } 1 \text { May } 2011 \text { under a } \\
\text { quota (NOAA 2011) }\end{array}$ \\
\hline Whip Stingray & Japan & -4557 & $\begin{array}{l}\text { No information on management. IUCN classified as Near } \\
\text { Threatened (Huveneers and Ishihara 2006) }\end{array}$ \\
\hline Portuguese Dogfish & $\begin{array}{l}\text { United Kingdom } \\
\text { Portugal }\end{array}$ & $\begin{array}{l}-1672 \\
-1108\end{array}$ & $\begin{array}{l}\text { IUCN classified the European populations of both the } \\
\text { Portuguese and Leafscale Gulper Shark as Endangered }\end{array}$ \\
\hline Leafscale Gulper & Portugal & -1538 & $\begin{array}{l}\text { (Stevens and Correia 2003; White 2003). In 2010, both } \\
\text { populations were subject to a zero TAC in EU waters } \\
\text { (Shark Trust; OSPAR Commission 2010) }\end{array}$ \\
\hline $\begin{array}{l}\text { Narrownose } \\
\text { Smooth-hound }\end{array}$ & Uruguay & -726 & $\begin{array}{l}\text { Classified as Endangered - no information on management } \\
\text { (Massa et al. 2006) }\end{array}$ \\
\hline
\end{tabular}


better reporting from Indonesia. Therefore, excluding Indonesia, the categories with the greatest increase are Blue Shark (49 549 t), Little Skate (4225), Shortfin Mako (3052), Thornback Ray (3042), 'Smooth-hounds nei' (2986) and 'Dogfish sharks nei' (2705).

\section{What percentage of global reported landings were reported from countries with management measures?}

We found that a large share of the global shark and ray landings reported between 2003 and 2011 appear to be subject to one or more of the management measures we considered (Fig. 4). Over a quarter $(29 \%)$ of the landings came were from countries signatory to the PSMA agreement but have yet to implement. Fourteen percent of the landings reported were from counties that ratified the PSMA. A quarter $(26 \%)$ of the landings were from signatories of CMS MoU sharks. Both PSMA and CMS MoU sharks have an implementation bias skewed towards Northern Hemisphere countries (Fig. 3a,b). Two-thirds (64\%) of landings were reported from countries with finalized SharkPlans, but only 9\% came from countries with relatively comprehensive Shark-Plans, those that met $65-85 \%$ of the objectives of sustainable fishing
(Fig. 4). Ten percent of landings were reported from countries with the strongest finning bans - a fins-attached policy. Countries with commercial fishing bans contributed little to the global reported landings. Five of the six countries with commercial fishing bans did not report any landings, the remainder accounted for less than one percent $(0.56 \%)$ of the global landings prior to implementation. A quarter $(27 \%)$ of the global shark and ray landings were from countries that did not report in any species-specific categories, while the majority of landings (75\%) were from countries reporting less than a quarter of their landings to species-specific categories. The bulk of the decline in global chondrichthyan catch $(80 \%)$ occurred in countries with two or fewer of the management measures considered here.

Countries with relatively stronger management measures in place showed modest declines in landings. Australia, United States and to a lesser extent Chile and Uruguay had Shark-Plans (addressing between 65 and $85 \%$ of the objectives) but three reported modest declines $(<2000 \mathrm{t})$ and the United States reported an increase in landings. The strongest finning policy, fins-attached, did show moderate signs of being associated with countries reporting a large share of the reductions: $30 \%$ of the decline is reported from countries with a fins-

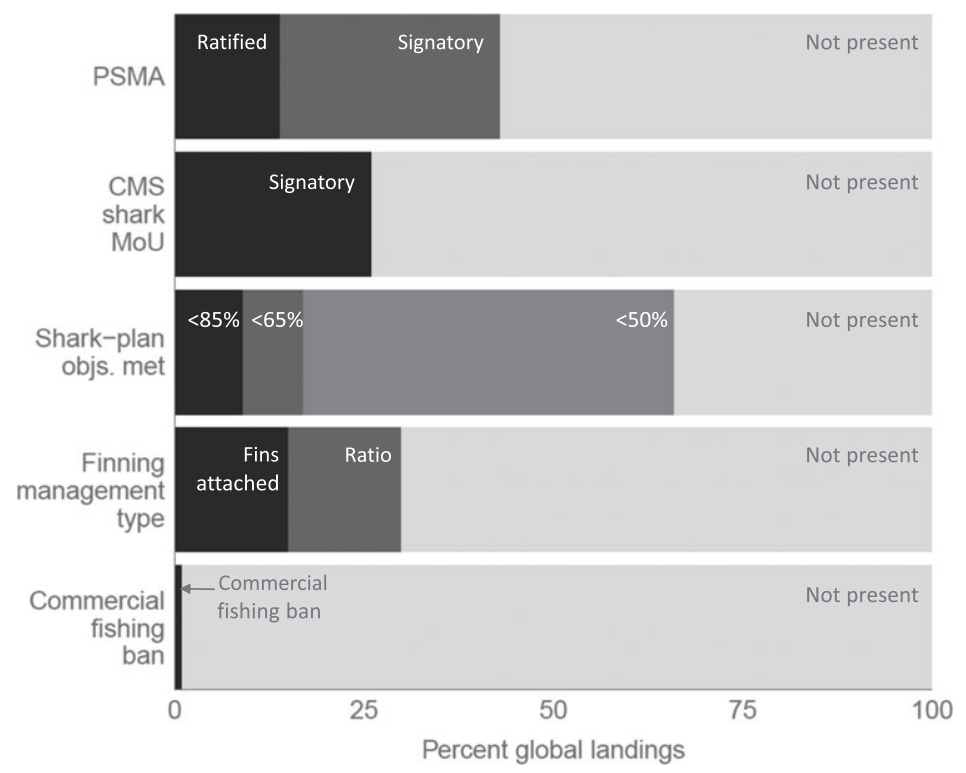

Figure 4 The percentage of global shark and ray landings reported from countries with the management measures we considered: PSMA, CMS MoU sharks, Shark-Plans, finning management or commercial fishing ban. The strongest management is represented by the black bar. The light grey bar represents the percentage of landings from countries that did not have/or were not party to the management measure. 
attached policy. This pattern was strongly influenced by Sri Lanka, which adopted fins-attached in 2001. Finally, 18 and 29\% of the global decline was reported from countries signatory to CMS MoU sharks or PSMA, respectively.

Was the global trend sensitive to influential countries or reporting categories?

Ten countries accounted for two-thirds (62\%) of global shark and ray landings from 2003 to 2011 (Fig. 5a). Removing Taiwan, the global trend was less steep ( $5 \%$ higher) (Fig. 5b). Indonesia reported the greatest landings, but they remained stable over time and therefore had negligible effect on the global landings trend (Fig. 5a,b). Spain reported the greatest landings increase, and there- fore, without their increased landings, the global trend would have been steeper ( $5 \%$ steeper $)$ (Fig. 4b).

Ten reporting categories accounted for fourfifths (83\%) of global landings reported from 2003 to 2011 (Fig. 4c). The taxonomically undifferentiated category of 'sharks, skates, rays, etc, nei' declined the most, and therefore, this category drove the overall global trajectory (Fig. 5c). Excluding 'sharks, rays, skates, etc, nei' revealed that the remaining landings would have been less steep (decline of 7\%) (Fig. 5d). Contrastingly, the decline in global landings would have been greater had it not been ameliorated by the dramatic increase in Blue Shark landings. Without Blue Shark landings, the global decline would have been $25 \%(10 \%$ steeper than the global trend)
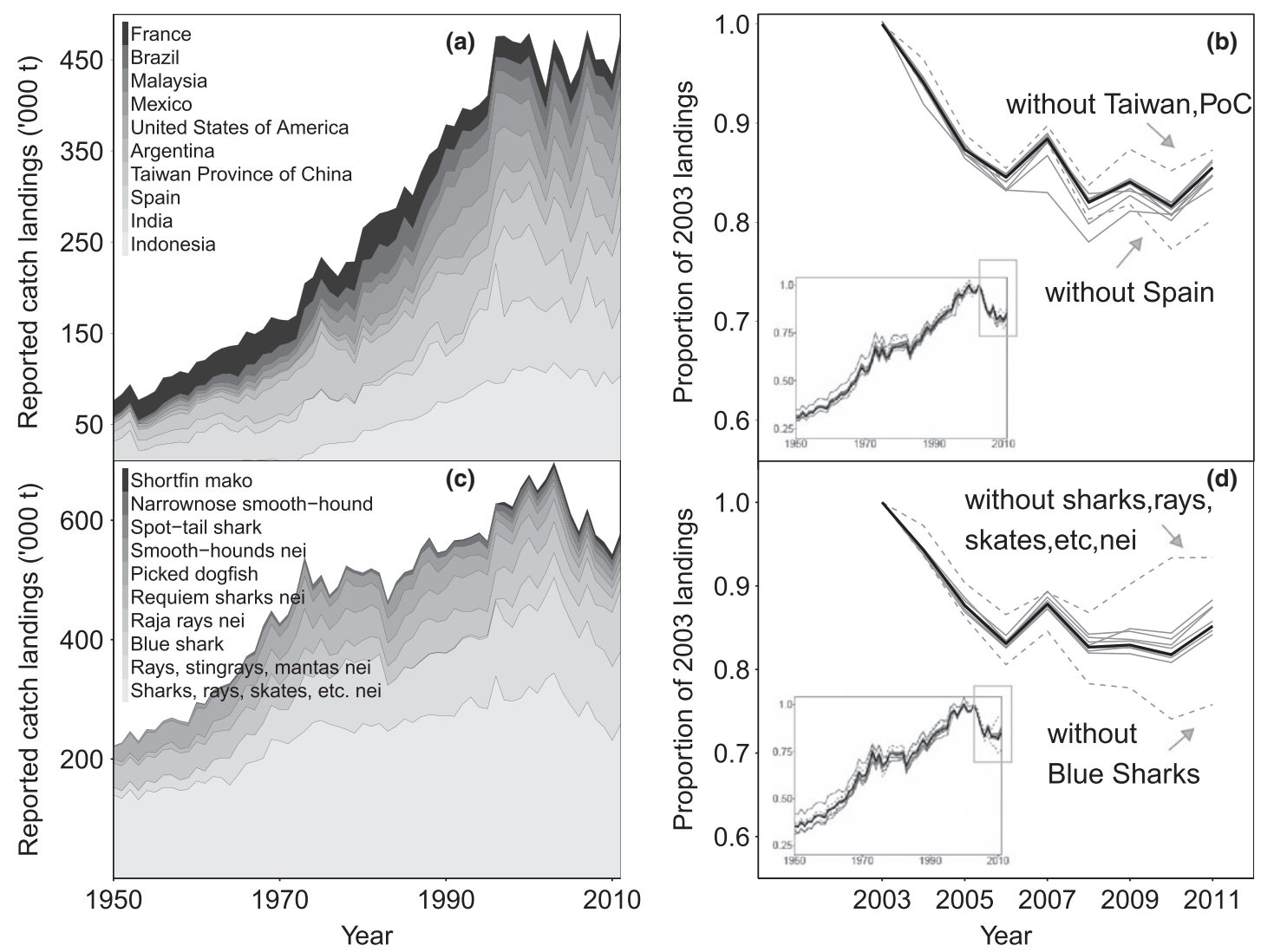

Figure 5 The sensitivity of the global landings trend to influential countries or reporting categories: (a) ten countries that reported the greatest landings between 2003 and 2011, (b) the influence of these ten country's landings on the global trajectory as determined by recalculating the trend in absence of their landings, (c) ten reporting categories with the greatest landings between 2003 and 2011, (d) the influence of these ten reporting categories on the global trajectory as determined by recalculating the trend in absence of their landings. 'Sharks, rays, skates, etc, nei' reported the greatest decline, and therefore, without this category, the global trend would be less steep. Without the dramatic increase in Blue Shark landings, the global trend would be steeper. 
(Fig. 5d). For this analysis, Indonesia's landings were not included to get a more accurate picture of changes in landings, rather than changes due to reporting category shifts. When Indonesia is included, Blue Shark and 'shark, ray, skate, etc, nei' still have the greatest influence (data not shown). Finally, the decline of reported landings in the 'sharks, rays, skates, etc, nei' category cannot be accounted for in the increased reporting in the 'Blue Sharks' category. Countries that reported declines in 'sharks, rays, skates, etc, nei' are not those that reported increased Blue Shark landings.

\section{What measures were most important in describing landings trajectories?}

Overfishing, rather than improved management, was the key driver of declines in shark and ray landings. The most important variables, across subsets of the data, that explained landings trajectories were two measures of indirect fishing pressure: (i) human coastal population size and (ii) shark and ray meat exports (Figs 6 and S3). The negative relationship suggested that countries with higher fishing pressure and trade experienced greater declines in landings (Figs $6 \mathrm{a}-\mathrm{c}$ and S3). While the effect was weaker, countries that reported greater fin exports, or higher estimated IUU fishing in their waters, reported marginally bigger declines in landings. As expected, all three ecosystem and species attributes explained substantial variability in the majority of models. Specifically, small tropical countries exhibited steeper declines, that is those with small EEZ's, high endemicity, high species richness. Average shark and ray landings reported between 2003 and 2011 were the most important across all model subsets and had a positive relationship; however, this variable was only to account for size of fishery and therefore not included in the Discussion.

By comparison, the influence of the indirect and direct management measures was marginal as shown in the partial dependence plots (Fig. S3). The most important management-related variable was a measure of the shortfall in scientific capacity: the percentage of DD species in the EEZ followed by Shark-plan year and strength, finning ban years, GDP and HDI, respectively. The relationship suggested, although the effect was marginal, that those countries with higher management capacity, higher affluence, or finning management in place for longer had reductions in their landings (Fig $6 \mathrm{a}-\mathrm{c}$ and S3). Five of the six unimportant variables however, were direct management measures, and only one fishing pressure measure was unimportant, marine protein in diet.

\section{Discussion}

While the foundations for improved management have been laid, our analyses showed that the implementation has been insufficient to account for the global reduction in shark and ray landings. Instead, it is more likely that the decline in shark and ray landings was due to reductions in fisheries catches due to population declines. The decline in shark and ray landings was strongly related to indirect and direct fishing pressure measures and only weakly related fisheries management measures. Our findings lead to six questions: (i) Is there additional evidence for shark and ray population declines? (ii) Did aggregate reporting influence our interpretation? (iii) What are the global priorities to promote shark and ray fisheries sustainability? (iv) Why have shark and ray landings decline? (v) Why area shark and ray management efforts not reflected in landings trajectories-yet? (vi) What effective fisheries management progress has been made?

\section{Is there additional evidence for shark and ray population declines?}

There are two independent lines of evidence for widespread shark and ray population declines. First, a recent analysis of the sustainability of the reported global catch (i.e. not accounting for discards or IUU fishing) suggests coastal species and large predators, such as sharks, were already heavily depleted by 1975 (Costello et al. 2012). By classifying FAO landings categories into 112 shark and ray fisheries, they found the average biomass of these shark fisheries was $37 \%$ of that which would provide maximum sustainable yield $\left(B_{\mathrm{MSY}}\right)$ (Costello et al. 2012). If $B_{\mathrm{MSY}}$ occurs at $30-50 \%$ of unexploited biomass, then by 2009 , the populations had on average declined by between $81 \%$ and $89 \%$ from the population baseline (Costello et al. 2012; Dulvy et al. 2014a). Second, the IUCN SSG estimates that $25 \%$ of all sharks and rays are threatened with elevated extinction risk (Vulnerable, Endangered or Critically Endangered) primarily as a result of steep declines due to overfishing (Dulvy et al. 2014a). 


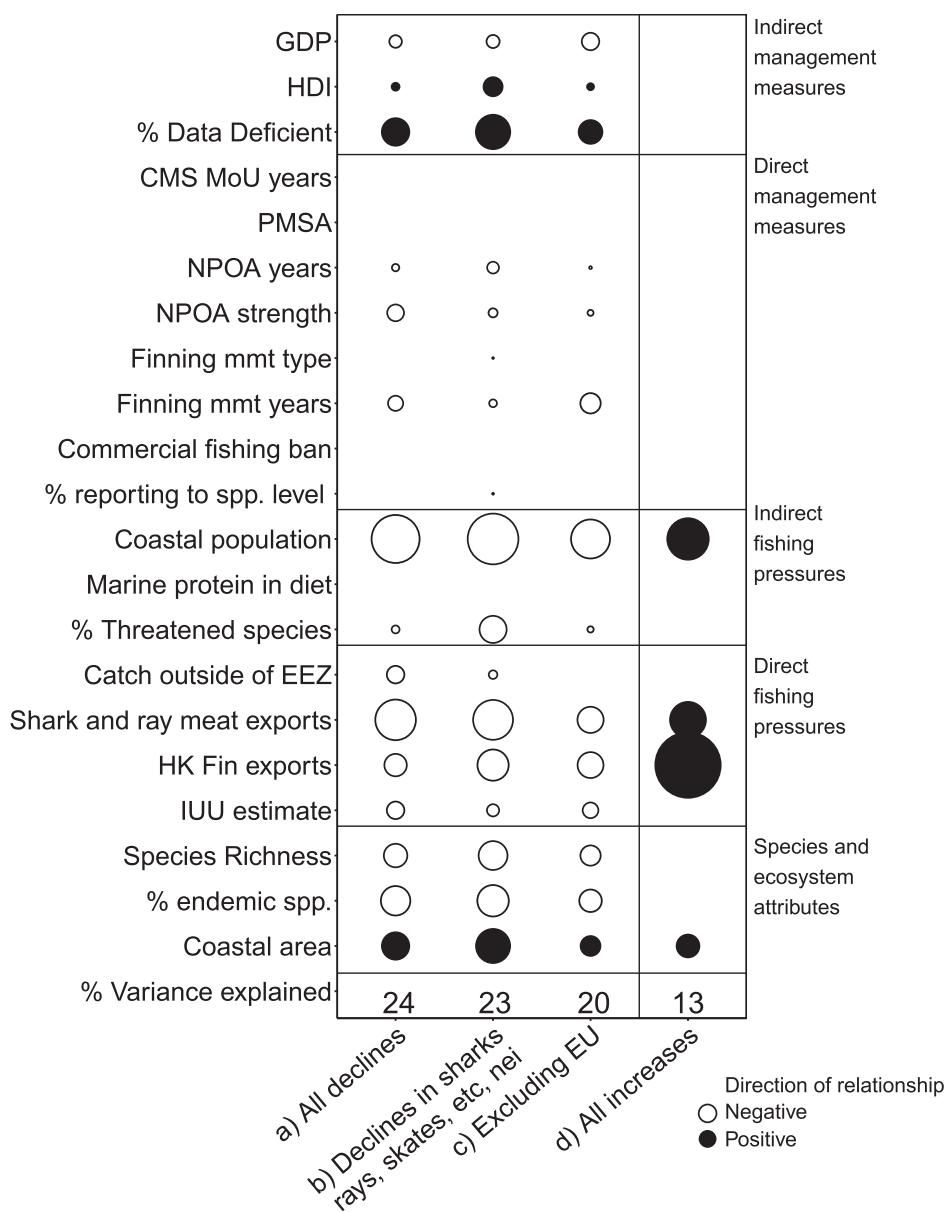

Figure 6 Variable importance dot plot for all model subsets. Size of dot represents the mean standard error associated with that variable from a random forest analysis. The larger the dot, the more important the variable is in describing the response. Hollow dots represent a negative relationship (see Fig. 3). Model output for (a) all countries reporting a decline; (b) country-specific declines only within the 'sharks, rays, skate, etc, nei' reporting category; (c) countries that reported a decline, with EU countries excluded; and (d) countries that reported an increase in landings.

\section{Did aggregate reporting influence our interpretation?}

We caution that those countries with stable or increasing shark and ray landings may not have sustainable shark and ray fisheries. In total, 62 countries (and overseas territories) reported stable trajectories $( \pm 150 \mathrm{t})$ and another 32 with increased landings. Stable or increased landings of aggregate species complexes have been shown to mask declines or disappearance of the most sensitive or more valuable species (Dulvy et al. 2000; Branch et al. 2013). For example, catches of skate species (Rajidae) reported as 'skates and rays' within British waters exhibited a stable trajectory. Yet, species-specific, fisheries-independent population trends revealed the disappearance of three of the largest skate species and steep declines in the two largest remaining species. The declines had been masked by compensatory rises in the abundance of the smaller species (Dulvy et al. 2000). Furthermore, the poor taxonomic resolution of fisheries landings data masked the near extinction of the Angel Shark (Squatina squatina) from European waters. This species was recorded and sold under the product name 'Monkfish'. The decline of the Angel Shark went almost entirely unnoticed because their dwindling catch was substituted with catches of anglerfish (Lophius spp.) sold under the same name (Dulvy and Forrest, 2010). Hence, accurate species-specific data on landed catch, and ideally discarded catch, are essential precursors to sustainable fisheries management. 
The FAO strongly recommend that all landings be reported to a species-specific level (Fischer et al. 2012). Species-specific reporting could be a condition of entry into fisheries or of fisheries licensing. Refining catches into species-specific categories will allow for better understanding of landings trends, lead to the improvement of management and inform the true status of individual stocks (Stevens et al. 2000). Similarly, fins-attached regulation can improve statistical reporting as carcasses brought back to port can be more readily identified (Fowler and Séret 2010). Transitioning to speciesspecific reporting will require considerable investment in training, which may require foreign assistance from richer countries with well-developed fisheries management, or cost recovery from the industry (Trebilco et al., 2010). We hope such activities are mainstreamed into the fisheries improvement activities of development agencies and NGOs (Dulvy and Allison 2009).

What are the global priorities to promote shark and ray fisheries sustainability?

Our study highlights a need to focus on the sustainability of Blue Shark and 'stingrays, butterfly rays nei' fisheries that have together increased by almost 100000 tonnes over 2003-2011. First, ensuring the sustainability of Blue Shark catches is of high importance given evidence for increased retention and the substantial contribution to global catches in the past decade. In Chile, the retention of Blue Shark increased almost 144\% from 2005 to 2010 (Bustamante and Bennett 2013). Globally, Blue Shark fins are estimated to comprise $17 \%$ of the overall fin market weight in Hong Kong (Clarke et al. 2006a). Blue Shark have comparatively higher rates of productivity than other shark and hence have great potential to be fished sustainably (Kleiber et al. 2009). According to assessments by scientists associated with Regional Fisheries Management Organizations (RFMO's), Blue Shark catches are thought to be sustainable in the Atlantic and Pacific, although no country in this region has adopted quotas or fishing limits for Blue Shark (Kleiber et al. 2009). There are concerns, however, that stock assessments are not reflecting the recent catch rate declines for Blue Shark, by $5 \%$ per year since 1996-2009, in the North Pacific (Clarke et al. 2013). Unfortunately, these stock assessments are driven by the longest, rather than the most pertinent time series, the latter of which suggests steep declines in catch rate.

Second, the rise of landings in 'stingrays, butterfly rays, nei' is mainly as a result of improved reporting by Indonesia. The rise in catches of rays (and skates) is concerning, however, because they are often overlooked by management and are generally more threatened than sharks (Dulvy et al. 2014a). Skates and rays (Batoids) are commercially exploited mainly for meat and the fins of the sharklike rays (Devil and Manta Rays (genus Mobula) are exploited for their gill plates). Steep declines have been noted for many skates and rays, including Sawfishes (Pristidae) (Dulvy et al. 2014a), and the largest skates such as the Common Skate (Dipturus 'batis' complex, Rajidae) (Brander 1981). Despite high risk and high exploitation rates, skates and rays were often overlooked in Sharks-Plans and finning bans (UN FAO 2013).

\section{Why have shark and ray landings declined?}

The most plausible explanation for the shark and ray declining landings, we observe, is that local and international demands are driving fishing pressure and over-exploitation.

Human coastal population size has repeatedly been shown to relate to indirect and direct measures of fishing pressure at a range of spatial scales from local to global. Catch rates, and direct and indirect effects of fishing are related to the number of islanders on coral reef islands (Jennings and Polunin 1996) and human coastal population density also relates to fisheries footprints and reef health at a regional (Dulvy et al. 2004; Mora 2008) and global scale (Newton et al. 2007). We also found that countries with high shark and ray meat exports reported larger declines, which indicates an important role of international meat trade in driving overfishing of sharks and rays (Clarke and Dent 2014).

\section{Why are shark and ray management efforts not reflected in landings trajectories-yet?}

We showed that there has undoubtedly been an increase in national and international commitments and policies specific to chondrichthyan fisheries in the past two decades. Our analyses show, however, that important international commitments have yet to be realized in the form of concrete fishing limits or restrictions on fishing for sharks and 
rays. This result is probably because the measures we considered, with the exception of CITES, are not yet legally binding, far from comprehensive, lacked clear implementation guidelines, operated with vague wording and lacked compliance monitoring (Lack and Sant 2011; Fischer et al. 2012). Here, we highlight some of the shortfalls and limitations of the PSMA, CMS MoU sharks, Shark-plans, finning bans and commercial fishing bans that resulted in little or no effect on global landings trajectories and provide suggestions for improvements.

Some of the international agreements and initiatives included in our analysis do not have widespread implementation. For example, the Port State Measures Agreement (PSMA) to combat IUU fishing is a new initiative (2009). To date, 26, plus the EU, countries have signed, but only five have ratified. Until ratified, the full potential of this agreement for improving fisheries sustainability cannot be realized. Addressing IUU fishing would have far reaching consequences for the sustainability of shark and ray fisheries (Doulman 2000). The global extent of IUU fishing for sharks and rays is unknown. The massive, uncontrolled catches of shark and rays in species-rich countries, in addition to the IUU fishing, are a major problem for the persistence of shark and ray populations. IUU fishing has been noted to be a major problem in Indonesia and for Vulnerable endemic sharks (Fischer et al. 2012; FAO 2014). Without controls on IUU fishing, it is estimated that fisheries management decisions are flawed subsequently leading to management goals not being met, and the potential, for the overfishing of populations (Doulman 2000; FAO 2013a).

Similarly, CMS MoU sharks potentially had not affected fisheries trajectories as the agreement included a few highly migratory, pelagic species. As of 2012, the eight species listed in the CMS sharks appendices represent $<15 \%$ of threatened, migratory sharks, and rays and no Endangered or Critically Endangered migratory shark or ray had been listed by CMS sharks (Fowler 2012). Also, the CMS needs a mechanism for compliance.

The national and regional Shark-Plans reviewed here are non-binding and have been found to emphasize early stages of fisheries management such as communication, finning management and forming partnerships rather than more direct catch and effort controls (Camhi et al. 2008). Shark-plans that were more comprehensive (i.e. Australia, United States, Canada) represented relatively sound management already in place (Dulvy et al. 2014a).

We found commercial fishing bans have been gazetted in countries with very small, or non-existent, commercial shark fisheries (as found in the past 60 years of the FAO landings records). Spatial protections that are strict and no-entry have been shown to increase predator biomass (Robbins et al. 2006). Commercial fishing bans, however, are not no-entry and countries often do not have the enforcement capacity to monitor large marine areas after implementation. For example, Palau has one enforcement boat to monitor the entire EEZ (GMS Vianna, personal communication). Additionally, commercial fishing bans may have limited future conservation benefits as a result of having no protections or management plans in place for shark by-catch mortality (Campana et al. 2011) and mortality from artisanal fishing (Hawkins and Roberts 2004), which can be significant. Therefore, we suggest that commercial fishing ban designation be expanded to rays and skates, to bycatch and to not forestall country participation in national and international fisheries management initiatives that promote sustainable resource utilization.

Derogations or loopholes exist that undermine the implementation and effectiveness of finning regulations. First, the relative weight of a shark's fins averages $3 \%$ but varies among species from 1.1 to $10.9 \%$ of the total weight of the animal (Biery and Pauly 2012). Second, the setting of a fin landing ratio is complicated by the choice of denominator - whole carcass, gutted carcass or dressed carcass (head removed) (Biery and Pauly 2012). Hence, the use of a blanket 5\% fin-to-carcass ratio (Fowler and Séret 2010) can allow for more sharks to be killed and disposed of further complicating mortality estimates (Biery and Pauly 2012). In addition, some countries have ratios higher than the recommended $5 \%$, and whether the percent ratio refers to dressed carcasses or whole bodies is unclear (Fowler and Séret 2010). Third, countries may allow for exceptions. Such as the EU which on November 2012 closed a loophole on a fins-attached rule that had been in effect since 2003. From 2003 to 2013, five EU countries were allowed to apply for Special Fishing Permits (SFP) exempting them from the finsattached policy. This exception became the rule for Portuguese and Spanish fishing fleets which held $220(91 \%)$ SFPs issued in 2005/2006 
(Fowler and Séret 2010). Fins naturally attached policy is the most reliable, is the easiest finning ban strategy to enforce (Fowler and Séret 2010) and would permit better data collection.

\section{What effective fisheries management progress has been made?}

There were considerable improvements in the management of shark and ray fisheries. First, Indonesia reported the largest landings of shark and rays to $\mathrm{FAO}$ and made considerable progress in taxonomic resolution of their landings in the past decade. Note, as of 2012 Spain reported the greatest landings (FAO 2013b). Prior to 2004, Indonesia reported $100000 \mathrm{t}$ of landings in two aggregate categories: 'sharks, rays, skates, etc, nei' and 'rays, stingrays, mantas nei' and in 2005 switched reporting into 11 family categories (Fischer et al. 2012). The majority of countries reported in an aggregate 'nei' category which therefore presents vast opportunity for each country to improve this necessary step towards effective management. Second, a number of species have recovered under strict management regulations. For example, White Shark populations increased in California after a prohibition on catches was implemented in 1994 (Burgess et al. 2014). Spiny Dogfish also recovered under strict catch quotas in the United States and the fishery re-opened in 2011 (COSEWIC 2011). Third, another encouraging sign of progress includes seven West African countries that developed a regional plan of action for shark and ray fisheries management. While non-binding and lacking fishing quotas, this coalition has led to improved knowledge of the major shark fisheries, increased landings surveys, improved public awareness, improved understanding of sawfish status and improved engagement with international conservation efforts such as the 2006 IUCN Red List assessment (Dulvy et al. 2014a). Similarly, South American countries (Chile, Columbia, Ecuador and Peru) worked together to develop a regional plan of action for the protection and management of chondrichthyans in this region (Gomez 2008).

\section{Conclusion}

We show that the management measures we considered had little influence on shark and ray fisheries landing trajectories. We interpret these findings, however, as a way to encourage the continued pressure on countries to prioritize the sustainable management of their shark and ray fisheries. Our analysis determined a number of countries and fisheries that deserve prioritization for conservation and management action. First, fisheries management development is necessary in the countries that report the greatest declines, such as Pakistan and Sri Lanka, and have little to no management in place. Second, countries reporting large increases, or a substantial portion of the world's landings can become the focus of conservation and management efforts to forestall potential impeding population declines (such as Indonesia, Philippines, India and Spain). Third, countries with relatively stronger management could improve further by sustainably managing fisheries that are of conservation concern and report landings to species-specific categories. These countries also could also work together and support developing countries with chondrichthyan management as sharks and rays are generally not confined to one national jurisdiction. Fourth, those fisheries with dramatic increases in landings need to be the focus of stock assessments and scientific management. Finally, we strongly suggest that countries implement the current scientific advice that includes, and is not limited to, catch limits, by-catch limits, finning bans, stock assessments and species-specific data collection.

\section{Acknowledgements}

We thank Sonja Fordham of Shark Advocates International for her contribution to study design, data acquisition and input. We also thank Sean Anderson, Heather Brekke, Maria José Juan Jordá, Chris Mull, Sebastián Pardo and Rowan Trebilco for constructive comments on early drafts. Thanks to Jason Brogan, Amanda Kissel, Rylee Murray, Earth to Ocean Research Group and Statzbeers for help along the way. We also thank two anonymous reviewers for helpful comments on earlier drafts. This project was funded by the Natural Science and Engineering Research Council of Canada and through Canada Research Chair, Glen Gleen Scholarship in Marine Biology, J. Abbott/M. Fretwell Fellowship in Fisheries Biology, Philip and Marian McClelland Memorial Scholarship. 


\section{References}

Allison, E.H., Perry, A.L., Badjeck, M.-C. et al. (2009) Vulnerability of national economies to the impacts of climate change on fisheries. Fish and Fisheries 10, 173-196.

Anderson, S.C., Cooper, A.B. and Dulvy, N.K. (2013) Ecological prophets: quantifying metapopulation portfolio effects. Methods in Ecology and Evolution 4, 971-981.

Barker, M.J. and Schluessel, V. (2005) Managing global shark fisheries: suggestions for prioritizing management strategies. Aquatic Conservation: Marine and Freshwater Ecosystems 15, 325-347.

Biery, L. and Pauly, D. (2012) A global review of species-specific shark-fin-to-body-mass ratios and relevant legislation. Journal of Fish Biology 80, 1643-1677.

Branch, T.A., Lobo, A.S. and Purcell, S.W. (2013) Opportunistic exploitation: an overlooked pathway to extinction. Trends in Ecology \& Evolution 28, 409-413.

Brander, K. (1981) Disappearance of common skate Raja batis from Irish Sea. Nature 290, 48-49.

Burgess, G.H., Bruce, B.D., Cailliet, G.M. et al. (2014) A re-evaluation of the size of the white shark (Carcharodon carcharias) population off California, USA. PLoS One 9, e98078.

Bustamante, C. and Bennett, M.B. (2013) Insights into the reproductive biology and fisheries of two commercially exploited species, shortfin mako (Isurus oxyrinchus) and blue shark (Prionace glauca), in the southeast Pacific Ocean. Fisheries Research 143, 174-183.

Camhi, M.D., Fordham, S.V. and Fowler, S.L. (2008) Domestic and international management. In: Sharks of the Open Ocean (eds M.D. Camhi, E.K. Pikitch and E.A. Babcock). Blackwell Publishing, Oxford, pp. 418-444.

Campana, S.E., Brading, J. and Joyce, W. (2011) Estimation of pelagic shark bycatch and associated mortality in Canadian Atlantic Fisheries. 25 pp. Research Document 2011/067. Science Advisory Secretariat. Fisheries and Oceans Canada.

Chassot, E., Bonhommeau, S., Dulvy, N.K. et al. (2010) Global marine primary production constrains fisheries catches. Ecology letters 13, 495-505.

Cinner, J.E., McClanahan, T.R., Daw, T.M. et al. (2009) Linking social and ecological systems to sustain coral reef fisheries. Current Biology 19, 206-212.

Clarke, S. (2004a) Shark Product Trade in Hong Kong and Mainland China and Implementation of the CITES Shark Listings. TRAFFIC East Asia, Hong Kong, China, 63 pp.

Clarke, S. (2004b) Understanding pressures on fishery resources through trade statistics: a pilot study of four products in the Chinese dried seafood market. Fish and Fisheries 5, 53-74.

Clarke, S. and Dent, F. (2014) State of the global market for shark commodities - summary of the draft FAO technical paper. CITES Animals Committee 27, Information Paper 14. www.cites.org/sites/default/files/ eng/com/ac/27/E-AC27-Inf-14.pdf. (accessed 11 April 2015).
Clarke, S.C., Magnussen, J.E., Abercrombie, D.L., McAllister, M.K. and Shivji, M.S. (2006a) Identification of shark species composition and proportion in the Hong Kong shark fin market based on molecular genetics and trade records. Conservation Biology 20 201-211.

Clarke, S.C., McAllister, M.K., Milner-Gulland, E.J. et al. (2006b) Global estimates of shark catches using trade records from commercial markets. Ecology Letters 9 , $1115-1126$.

Clarke, S.C., Harley, S.J., Hoyle, S.D. and Rice, J.S. (2013) Population trends in Pacific Oceanic sharks and the utility of regulations on shark finning. Conservation Biology 27, 197-209.

CMS (2013) CMS sharks MoU. Available at: http:// sharksmou.org/ (accessed 20 May 2011).

COSEWIC (2011) COSEWIC Assessment and Status Report on the North Pacific Spiny Dogfish (Squalus suckleyi) in Canada. Committee on the Status of Endangered Wildlife in Canada, Ottawa, Canada. 45 pp.

Costello, C., Ovando, D., Hilborn, R., Gaines, S.D., Deschenes, O. and Lester, S.E. (2012) Status and solutions for the world's un-assessed fisheries. Science 338, 517-520.

Davidson, L.N.K. (2012) Shark sanctuaries: substance or spin? Science 338, 1538.

DFO (2007) Assessment of Spiny Dogfish in Atlantic Canada. DFO Canadian Science Advisory Secretariat Science Advisory Report 2007/046, Dartmouth, Nova Scotia. $23 \mathrm{pp}$.

Doulman, D.J. (2000) Illegal, Unreported and Unregulated Fishing: Mandate for an International Plan of Action. Document AUS:IUU/2000/4. Rome, Italy, 16 pp. Available at: www.fao.org/docrep/005/Y3274E/y3274e06.htm (accessed 11 April 2015).

Dulvy, N. and Allison, E. (2009) A place at the table? Nature Reports Climate Change 26, 61.

Dulvy, N.K. and Forrest, R.E. (2010) Life histories, population dynamics, and extinction risks in chondrichthyans. In: Sharks and their Relatives II: Biodiversity, Adaptive Physiology, and Conservation. (eds J.C. Carrier, J.A. Musick and M.R. Heithaus). CRC Press, Boca Raton, pp. 635-676.

Dulvy, N.K., Metcalfe, J.D., Glanville, J., Pawson, M.G. and Reynolds, J.D. (2000) Fishery stability, local extinctions, and shifts in community structure in skates. Conservation Biology 14, 283-293.

Dulvy, N.K., Freckleton, R.P. and Polunin, N.V.C. (2004) Coral reef cascades and the indirect effects of predator removal by exploitation. Ecology Letters 7, 410-416.

Dulvy, N.K., Fowler, S.L., Musick, J.A. et al. (2014a) Extinction risk and conservation of the world's sharks and rays. eLife 3, e00590.

Dulvy, N.K., Pardo, S.A., Simpfendorfer, C.A. and Carlson, J.K. (2014b) Diagnosing the dangerous demography of manta rays using life history theory. PeerJ $\mathbf{2}$, e400. 
FAO (2013a) Agreement on Port State Measures to Prevent, Deter, and Eliminate Illegal, Unreported, and Unregulated Fishing. Rome, Italy. Available at: www.fao.org/fishery/topic/166283/en (accessed 11 April 2015).

FAO (2013b) FISHStat. FishStat Plus Universal Software for Fishery Statistical Time Series. Rome, Italy. Available at: www.fao.org/fishery/statistics/software/fishstat/en (accessed 11 April 2015).

FAO (2014) The State of World Fisheries and Aquaculture. Food and Agriculture Organization of the United Nations, Rome, Italy, 243 pp.

FAO (2010) The State of the World Fisheries and Aquaculture. Food and Agriculture Organization of the United Nations, Rome, Italy, 218 pp.

Field, I.C., Meekan, M.G., Buckworth, R.C. and Bradshaw, C.J.A. (2009) Protein mining the world's oceans : Australasia as an example of illegal expansion-anddisplacement fishing. Fish and Fisheries 10, 323-328.

Fischer, J., Erikstein, K., D’Offay, B., Barone, M. and Guggisberg, S. (2012) Review of the Implementation of the International Plan of Action for the Conservation and Management of Sharks. Food and Agriculture Organization of the United Nations, Rome, 125 pp.

Fisheries Agency (2009) Japan's National Plan of Action for Conservation and Management of Sharks Revised Version. Fisheries Agency, 4 pp. Available at: www.fao.org/ fishery/ipoa-sharks/npoa/en (accessed 11 April 2015).

Fishery Agency (2004) Taiwan's National Plan of Action for the Conservation and Management of Sharks. Council of Agriculture, $7 \mathrm{pp}$.

Fordham, S.V. (2004) Conservation and Management Status of Spiny Dogfish Sharks (Squalus acanthias). AC20 Inf. 22, pp. 1-7. Available at: www.cites.org/sites/ default/files/common/com/ac/20/E20i-22.pdf (accessed 11 April 2015).

Fowler, S.L. (2012) First meeting of the signatories to the Memorandum of Understanding on the conservation of migratory sharks. In: Background Paper on the Conservation Status of Migratory Sharks. Bonn, Germany, 24-27 September Agenda Item 7, 26 pp.

Fowler, B.S. and Séret, B. (2010) Shark Fins in Europe: Implications for Reforming the EU Finning Ban. European Elasmobranch Association and IUCN Shark Specialist Group, Plymouth and Burnaby, $27 \mathrm{pp}$.

García, V.B., Lucifora, L.O. and Myers, R.A. (2008) The importance of habitat and life history to extinction risk in sharks, skates, rays and chimaeras. Proceedings of the Royal Society B: Biological Sciences 275, 83-89.

Gomez, D.J.L. (2008) Plan de Acción Regional para la conservación de tiburones, rayas y quimeras en el Pacífico Sudeste (PAR-CPPS). Comision Permanente del Pacifico Sur - CPPS, Universidad Austral de Chile, Valdivia, pp 35.

Gutiérrez, N.L., Hilborn, R. and Defeo, O. (2011) Leadership, social capital and incentives promote successful fisheries. Nature 470, 386-389.
Hareide, N., Carlson, J., Clarke, M. et al. (2007) European Shark Fisheries: A Preliminary Investigation into Fisheries, Conversion Factors, Trade Products, Markets and Management Measures. European Elasmobranch Association, 71 pp. Available at: http://sasama.info/en/pdf/ Hareide_2007.pdf (accessed 11 April 2015).

Hawkins, J.P. and Roberts, C.M. (2004) Effects of artisanal fishing on Caribbean coral reefs. Conservation Biology 18, 215-226.

Huveneers, C. and Ishihara, H. (2006) Dasyatis akajei. The IUCN Red List of Threatened Species. Version 2014.3. Available at: www.iucnredlist.org (accessed 11 April 2015).

Jennings, S. and Polunin, N. (1996) Effects of fishing effort and catch rate upon the structure and biomass of Fijian reef fish communities. Journal of Applied Ecology 33, 400-412.

Juan-Jordá, M.J., Mosqueira, I., Cooper, A.B., Freire, J. and Dulvy, N.K. (2011) Global population trajectories of tunas and their relatives. Proceedings of the National Academy of Sciences USA 108, 20650-20655.

Kleiber, P., Clarke, S., Bigelow, K., Nakano, H., Mcallister, M. and Takeuchi, Y. (2009) North Pacific Blue Shark Stock Assessment. NOAA Technical Memorandum., NOAA-TM-NMFS-PIFSC-17. Pacific Islands Fisheries Science Center. National Oceanic and Atmospheric Administration, 74 pp.

Lack, M. and Sant, G. (2011) The Future of Sharks? A Review of Action and Inaction. TRAFFIC International and the PEW Environment Group, Cambridge, pp. $1-44$.

Lam, V.Y.Y. and Sadovy de Mitcheson, Y. (2011) The sharks of South East Asia - unknown, unmonitored and unmanaged. Fish and Fisheries 12, 51-74.

Liaw, A. and Wiener, M. (2002) Classification and regression by randomForest. $R$ News $\mathbf{2}, 18-22$.

Loreau, M., Naeem, S., Inchausti, P. et al. (2001) Biodiversity and ecosystem functioning: current knowledge and future challenges. Science 294, 804-808.

Massa, A., Hozbor, N., Chiaramonte, G., Balestra, A. and Vooren, C. (2006) Mustelus schmitti. The IUCN Red List of Threatened Species. Version 2014.3. Available at: www.iucnredlist.org.

Mellin, C., Bradshaw, C.J.A., Fordham, D.A. and Caley, M.J. (2014) Strong but opposing $\beta$-diversity - stability relationships in coral reef fish communities. Proceedings of the Royal Society B: Biological Sciences 281, 20131993.

Mora, C. (2008) A clear human footprint in the coral reefs of the Caribbean. Proceedings of the Royal Society B: Biological Sciences 275, 767-773.

Mora, C., Myers, R.A., Coll, M. et al. (2009) Management effectiveness of the world's marine fisheries. PLoS One 7, e1000131.

MRAG and Fisheries Ecosystems Restoration Research (2008) The Global Extent of Illegal Fishing. Fisheries 
Centre, University of British Columbia, Vancouver, Canada, 41 pp.

Myers, R.A., MacKenzie, B.R., Bowen, K.G. and Barrowman, N.J. (2001) What is the carrying capacity for fish in the ocean? A meta-analysis of population dynamics of North Atlantic cod. Canadian Journal of Fisheries and Aquatic Sciences 58, 1464-1476.

NASA Earth Data Socioeconomic data and application center (SEDAC). Available at: http://sedac.ciesin.columbia.edu/data/set/nagdc-population-landscape-climateestimates-v3 (accessed 11 April 2015).

Newton, K., Côté, I.M., Pilling, G.M., Jennings, S. and Dulvy, N.K. (2007) Current and future sustainability of island coral reef fisheries. Current Biology 17, 655658.

NOAA (2011) 2011 Spiny Dogfish Fishery. United States Department of Commerce. Available at: www.greateratlantic.fisheries.noaa.gov

OSPAR Commission (2010) Background Document for Portuguese Dogfish (Centroscymnus coelolepis). OSPAR Commission, London, UK, pp. 1-19.

PEW charitable trusts (2013) Global Shark Conservation: Sanctuaries for a Predator in Peril. PEW charitable trusts, $13 \mathrm{pp}$.

Pitcher, T.J. and Hart, P.J. (1982) Fisheries Ecology, 1st edn. Ipswish Book Co., London.

Pitcher, T., Kalikoski, D., Pramod, G. and Short, K. (2009) Not honouring the code. Nature 457, 658659.

Pompa, S., Ehrlich, P.R. and Ceballos, G. (2011) Global distribution and conservation of marine mammals. Proceedings of the National Academy of Science USA 108, 13600-13605.

R Core Team (2014) R: A Language and Environment for Statistical Computing. R Foundation for Statistical Computing, Vienna, Austria. Available at: www.R-project. org (accessed 11 April 2015).

Ricard, D., Minto, C., Jensen, O.P. and Baum, J.K. (2012) Examining the knowledge base and status of commercially exploited marine species with the RAM Legacy Stock Assessment Database. Fish and Fisheries 13, 380-398.

Robbins, W.D., Hisano, M., Connolly, S.R. and Choat, J.H. (2006) Ongoing collapse of coral-reef shark populations. Current Biology 16, 2314-2319.

Shark Advocates International (2012) Sri Lanka Protects Thresher Sharks. Available at: www.sharkadvocates.org (accessed 11 April 2015).

Shark Specialist Group (2013) IUCN Shark Specialist Group. Available at: www.iucnssg.org (accessed 11 April 2015).

Shark Trust Leafscale Gulper Shark ID Guide. 2. Available at: www.sharktrust.org/en/shark_factsheets (accessed 11 April 2015).

Smith, M.D., Roheim, C.A., Crowder, L.B. et al. (2010) Sustainability and Global Seafood. Science 327, 784-786.
Stevens, J. and Correia, J.P. (2003) Centroscymnus coelolepis. The IUCN Red List of Threatened Species. Version 2014.3. Available at: www.iucnredlist.org (accessed 11 April 2015).

Stevens, J., Bonfil, R., Dulvy, N. and Walker, P. (2000) The effects of fishing on sharks, rays, and chimaeras (chondrichthyans), and the implications for marine ecosystems. ICES Journal of Marine Science 57, 476494.

Stevens, J., Walker, T., Cook, S., Fordham, S. (2005) Threats faced by chondrichthyan fishes. In: Sharks, Rays, Chimaeras: the Status of the Chondrichthyan Fishes (eds S. Fowler, R. Cavanagh, M. Camhi et al.). IUCN Species Survival Commission Shark Specialist Group, Gland, Switzerland and Cambridge, UK, pp. 48-57.

Strobl, C., Boulesteix, A.L., Kneib, T., Augustin, T. and Zeileis, A. (2008) Conditional variable importance for random forests. BMC Bioinformatics 9, 1-11.

The Government of the Hong Kong Special Administrative Region of the People's Republic of China (2012) Hong Kong Census and Statistics Department. Available at: http://www.censtatd.gov.hk/

Trebilco, R., Gales, R., Lawrence, E., Alderman, R., Robertson, G. and Baker, G.B. (2010) Characterizing seabird bycatch in the eastern Australian tuna and billfish pelagic longline fishery in relation to temporal, spatial and biological influences. Aquatic Conservation: Marine Freshwater Ecosystems 20, 531-542.

UN FAO (2013) About the IPOA-Sharks. Available at: www.fao.org/fishery/ipoa-sharks/about/en.

United Nations Development Programme (2011) Human Development Reports. Available at: http://hdr.undp.org/ en/ (accessed 11 April 2015).

United Nations General Assembly (2007) Resolution Adopted by the General Assembly. Resolution 61/105 Sustainable fisheries. 06-50073. 1-21 pp. Available at: http://research.un.org/en/docs/ga/quick/regular/61

Vincent, A.C.J., Sadovy de Mitcheson, Y.J., Fowler, S.L. and Lieberman, S. (2013) The role of CITES in the conservation of marine fishes subject to international trade. Fish and Fisheries 15, 563-592.

VLIZ (2012) Flanders Marine Institute. Available at: www.vliz.be/en/ (accessed 11 April 2015).

Watson, R., Zeller, D. and Pauly, D. (2013) Primary productivity demands of global fishing fleets. Fish and Fisheries 15, 231-241.

White, W.T. (2003) Centrophorus squamosus. The IUCN Red List Threatened Species. Version 2014.3. Available at: www.iucnredlist.org (accessed 11 April 2015).

Witbooi, E. (2014) Illegal, unreported, unregulated fishing on the high seas: the port state measures agreement in context. The International Journal of Marine and Coastal Law 29, 290-320. 


\section{Supporting Information}

Additional Supporting Information may be found in the online version of this article:

Figure S1. Pearson's correlation table.

Figure S2. Percentage of a county's landings reported to species level.

Figure S3. Random Forest partial dependence plots of important variables from (a) the model that explained the most variance - all countries reporting a decline. Variables are order from left to right, top to bottom in terms of importance (see
Figure 8a). (b) countries reporting an increase in landings.

Table S1. Summary table of all predictor variables and definitions. Variables are organized according to their broad category class (Fig. 1).

Table S2. Summary of commodity codes for shark and ray meat exports and total reported tonnes for 2003 and 2009 (the most recent data).

Table S3. Countries reporting the greatest increase in landings between 2003 and 2011 in descending order. 